\title{
"The dance of the intelligence"? Dancing Bodies in Mina Loy
}

Mina Loy's engagement with the visual and plastic arts has been well documented in critical accounts of her writing and other activities as a modernist woman. Loy lived in some of the most vibrant locations of modernist endeavour - Florence, Berlin, New York, Paris - and mingled with many of modernism's key figures - Pound, Stein, Joyce, Duchamp. She was an artist and designer so when she wrote a visual perspective informed her poetry and prose; Loy's writing abounds with instances of her attempts to render into words the experience of viewing a sculpture, painting or other art object. As well as examining this use of ekphrasis, several critics have considered the ties between Loy's poetry and music, ${ }^{1}$ but what have been overlooked are the resonances between Loy's writing and dance and the different ways in which her writing engages with the prominent forms and figures of dance of her era. In her writing on dance Loy foregrounds the (gendered) body and challenges dominant discourses which elide the singularity of the dancing figure and translate her kinaesthetic into signs (words, ideas), that is, into a system which privileges the intellect over immanence. Dance in Loy's writing is inextricably connected to the particularity of embodied expression, a key concern in her poetry and other writing. As this article will argue, dance for Loy bodies forth an expression which inverts the substitutions of intellection and externalises cognition as proprioception; it plays a key role in the articulation of her feminist aesthetics.

Since her recovery from the margins of canonical modernism Loy's work has been discussed in relationship to the pantheon of men avant-gardists and modernists she encountered in her life, men such as Fillipo Tommaso Marinetti, Arthur Cravan, Ezra Pound, Marcel Duchamp, Richard Oelze, and Joseph Cornell. And although Loy wrote a substantial amount on 
concert dance and contemporary dance cultures, she features fleetingly, if at all, in recent accounts of the influence of dance on modernist literature and aesthetics, accounts which generally emphasize the thought and work of key men: Loy warrants just two passing references in Susan Jones' Literature, Modernism and Dance. ${ }^{2}$ In explicating Loy's various representations of dance and the dancer the following pages begin by establishing her resistance to a male modernist co-option of dance as a form of modernist poetics and by salvaging her distinct contribution to modernist thinking about dance from accounts that overlook her work or inevitably refer to the men in her life. Over the course of her writing career Loy returned to dance as gender complex, as a popular genre and finally as a stage for the realisation of a distinct, feminine subjectivity. Unlike other women writers of the time, such as Willa Cather, Djuna Barnes and Marianne Moore, Loy did not publish articles or critical accounts of famous dancers or troupes. ${ }^{3}$ Her knowledge of and engagement with dance nevertheless exemplifies how a woman writer could use this corporeal art as a window onto a feminist sensibility. In a period when dance was undergoing similar seismic shifts to those transforming the written and visual arts, Loy drew on ballet and modern dance and the performative energies of the moving form to scrutinize the politics of the gendered body and to examine the generation of non-verbal, expressive kinaesthetics.

In April 1915 Mina Loy's poem 'Sketch of a Man on a Platform' was published in the Greenwich Village little magazine Rogue. ${ }^{4}$ This was the first of six pieces Loy published in Rogue and it offers a portrait of Marinetti, Loy's one-time lover and the bombastic leader of Italian futurism who infamously declared a 'contempt for women'. ${ }^{5}$ Cinzia Blum's recent exploration of the performative rhetoric of Marinetti's 'self-transfiguring embodiment of the futurist superuomo' points to the 'theatricality' and 'rhetorical surfeit' Marinetti self-consciously deploys. This involves the incorporation of a range of contradictions but Blum concludes that this 'fiction and 
performance of hyper-virility' falls far short of exposing it 'in proto-feminist fashion, as a masquerade'. ${ }^{6}$ In her account of Marinetti speaking in public, however, Loy does just this, exposing the masquerade of his virile posturing by offering an incongruous comparison for his movements:

Savor of the airy-fairy of the ballet

The essence of Mademoiselle Genée

Winks in the to-and-fro of your cuff-links

Mademoiselle Adeline Genée (born Anina Kirstina Margarete Petra Jensen in Denmark in 1878) was a world-renowned ballerina who starred at the Empire Theatre of Varieties in London between 1897 and 1907, subsequent to which she appeared in New York (in 1908-9, 1912 and 1914), and toured across the USA and to Australia and New Zealand. In her first appearances in New York Genée danced interludes in musical comedies produced by Florenz Ziegfeld, and Klaw and Erlanger, rather than full ballet performances. For her American audiences, however, Genée embodied a graceful, European ballet tradition and presented what Mary Simonson describes as, 'a legitimate alternative to American early modern dance' as exemplified by Isadora Duncan. ${ }^{7}$ Mention of Genée’s light, delicate and refined technique was prominent in reviews with accounts describing her dance in the exact vocabulary that Loy uses in her poem: 'Dainty and airy, Genée's dancing is touched with vivid pantomime and elfish humor'; 'the "airy fairy" grace of her dancing'; 'Genée was a sylph, a fairy, a premiere danseuse of high quality, a delicately fragile little lady whose art was at its most exquisite in airy flutterings'. ${ }^{8}$ It is Genée's 'airy-fairy' balletic grace that Loy ironically attributes to Marinetti's platform performance of futurist masculinity. 
Marinetti did pay attention to ballet in his 1917 'Manifesto of Futurist Dance', declaring the 'glorious Italian ballet' 'dead and buried"' and proposing three 'anti-harmonic', 'asymmetrical', 'synthetic' Futurist dances based on 'mechanisms of war. ${ }^{10}$ He does though find time to admire the 'muscular' 'geometry' of Vaslav Nijinksy, the star male dancer with Diaghilev's Ballets Russes, and observe the 'languid' 'rhythm of a woman's body' that animates Isadora's Duncan's 'free dance. ${ }^{11}$ Marinetti’s earlier manifesto, 'The Variety Theatre' (1913), celebrates the central place of dance in the variety theatre's 'healthiest of all spectacles [...] its dynamism of form and colour'; Marinetti applauds the 'spiral cyclones of dancers spinning on the points of their feet'. ${ }^{12}$ Genée was renowned for her 'classical elève' and 'the magic of her twinkling feet, ${ }^{13}$ but Loy's evocation of her 'essence' in Marinetti's futurist performance travesties ${ }^{14}$ him rather than endorses his futurist ideas about dynamism and popular entertainment. Loy's other satirical portraits of Marinetti, particularly the unpublished play 'Sacred Prostitute' and short story 'Pazzerella', similarly travesty the virile, aggressive masculinity of the futurist, though in these texts it is the interchange and dialogue with a women character which deconstructs his male self-assertion. ${ }^{15}$ In 'Sketch of a Man on a Platform' Loy's Marinetti carries the 'savor,' the taste and trace, of Genée's ballet dancing. This simultaneously objectifies and feminizes his body and gestures towards the non-normative masculinities performed by a new generation of modern, male dancers.

The male dancer had all but disappeared from the European stage in the mid-nineteenth century, ${ }^{16}$ and it was only with the Ballets Russes, which introduced Nijinsky and Léonide Massine as dancing stars, that a man's dancing body became the focus of the audiences' attention. Peter Stoneley describes how '[w]ithin a few short years, Diaghilev had transformed the ballet from a spectacle that focused on the female ballerina to one that focused on the man, ${ }^{17}$ but the sexual politics of this male spectacle were complex. Nijinsky's roles in ballets choreographed by Michel Fokine and himself were 'heterodox'18 and included the 'trangressively 
sensual and eroticized male image' of the Golden Slave in Schébérezade (1910), ${ }^{19}$ the 'phallic pathos' arising from the coupling of a display of male strength and virtuosity with a costume of fluttering pink-red petals in Le Spectre de la rose (1911), ${ }^{20}$ the auto-erotic climax of L'Aprés midi d'un faune (1912) and the uncertainly-gendered sexual triangle of Jeux (1913). Thus, even Nijinsky's 'muscular' 'geometry' was legible as a (homo)erotic spectacle with his presence on stage functioning to challenge audience expectations about essential masculinity. Loy's reference to ballet in 'Sketch of a Man on a Platform' is not unique and she repeats her queering of masculinity through the ballet dancer in the poem 'Crab-Angel,' (1922) which depicts a dwarf circus-acrobat, cross-dressed in ballerina's tutu as a 'minnikin of masquerade sex'. ${ }^{21}$ Loy parodically queers futurist masculinity in other works, notably 'Giovanni Franchi' (1915) with its 'incriminating portrait of the Futurist as Pederast' as Roger Conover put it. ${ }^{22}$ As a (dancing) man on a platform, Loy's Marinetti is made available to his audience as a spectacular body enacting an ambivalently queered masculinity that undercuts his heterosexist, public persona.

Just as she satirises and resists the masculinism of Marinetti's modernism, presenting him in an uncertainly gendered body dancing futurist rhetoric, Loy satirised another influential modernist man, Ezra Pound, who sought to co-opt her writing into a different version of the dance. Both Susan Jones and Felicia McCarren explain how Pound's modernist aesthetic drew on the energy of the dancing body to theorise the rejuvenation of the poetic word: his conceptualization of modern aesthetics drew on dance as a 'metaphorical aid' in which the 'force and dynamics of the moving body [functioned] as a corollary for the spatial and temporal aspects of a modernist poetics ${ }^{23}$ Specifically, in his later thinking on logopoeia, Pound writes that ' $[t]$ he thinking word-arranging, clarifying faculty must move and leap with the energising, sentient, musical faculties. ${ }^{24}$ The dancing intelligence of logopoeia, therefore, translates the rhythm of the active body into active poetic language. 
However, Pound's earliest definition of logopoeia finds inspiration, not just in dance, but in the poetry of Mina Loy. In attempting to define the work of Loy and her Others compatriot Marianne Moore in his March 1918 review section for The Little Review, ‘A List of Books,' Pound first presented the category of

logopoeia or poetry that is akin to nothing but language, which is a dance of the intelligence among words and ideas and modification of ideas and characters. Pope and the eighteenth-century writers had in this medium a certain limited range. The intelligence of Laforgue ran through the whole gamut of his time. T. S. Eliot has gone on with it. Browning wrote a condensed form of drama, full of things of the senses, scarcely ever pure logopoeia. ${ }^{25}$

By characterising Loy's poetry through logopoeia as 'akin to nothing but language' and aligning her with Laforgue, Pound emphasised the ironic and linguistic complexity of her work. Carolyn Burke, the first of many critics to engage with Pound's use of Loy in his definition of logopoeia, argues that this form of poetry, as posited by Pound, 'was practised by, and appealed to, a selfconscious elite. ${ }^{26}$ The elitism of the logopoeic method is further suggested by its obscure historical and international antecedents, as Pound states quite bluntly, 'If you really want to understand what I am talking about you will have to read, ultimately, Propertius and Jules Laforgue' and of course Alexander Pope. ${ }^{27}$ It is clear as Pound asserts ('I intend this as praise'), that he means to commend the 'American' achievement of Loy and Moore in his 'A List of Books', and to place their work in its correct context. ${ }^{28}$ However, whilst gesturing towards the possibility of somatic meanings and the role of the body in the production of knowledge with his description of logopoeia as a 'dance,' Pound's aesthetic transmutes the body into linguistic energy, using the dancer as a metaphor whilst effacing the materiality of the dancer herself. 
Dance actually engenders meaning in and of the body and produces 'a range of kinaesthetic pleasures and responses [for] spectators, ${ }^{29}$ but for Pound it remains what McCarren describes as merely 'a model for modernism's poetic and visual codes. ${ }^{30}$ He neglects to recognise the autonomous, kinaesthetic meaning that dance produces. In her response to Pound and in her other writings on dance Loy explores the tension between abstraction and representation in figuring the dancing body and highlights the silencing of women's embodied experience that often attends a masculine intellectual pursuit of the dancer's bodily art.

Loy was not simply dismissive of Pound, acknowledging his central role in publicising modernism and describing him as 'the masterly impresario of modern poets' in 'Modern Poetry', ${ }^{31}$ but her poem 'The Black Virginity' (1918) ${ }^{32}$ satirically responds to Pound's characterisation of her logopoeic method and his version of the dance. If Pound framed her poetic as an act of intellection, wherein the movement of an embodied intelligence becomes an object of poetic articulation (dance as a noun rather than a verb), then Loy responds by imagining the ironic embodiment of an abstract philosophy (in her poem's 'Baby Priests') whilst sardonically snubbing Pound's 'Uneasy dreaming' of her logopoeic method.

'The Black Virginity' is linked with Loy's poems 'Virgins Plus Curtains Minus Dots' (1915) and 'Magasins du Louvre' (1915), poetic examinations of the fabricated nature of virginity and female value and the restriction of women within such ideologies of gender and the body. But the seminarians in 'The Black Virginity' share common ground with Loy's 'Sketch of a Man on a Platform,' their gendered position made unstable through their association with the typically feminine position of 'vestal' 'virginity'. They are endowed with an imaginative life which directs them towards the Catholic primacy but, nonetheless, in its disavowals introduces a feminine presence:

Evangelical snobs

Uneasy dreaming 
In hermetically-sealed dormitories

Not of me or you Sister Saraminta

Of no more or less

Than the fit of Pope's mitres

These lines negotiate and undermine the closure of a system implying the potential for disturbance or disruption to the 'hermetically-sealed.' This phrase infers the privacy of the system of knowledge, open only to the initiated, but also serves to reinforce the possibility of disruption from the outside, by physicality, or the uninitiated, for example. ${ }^{33}$ In an attempt to abjure the outside, the other, the hermetic system focuses on internal, intellectual deliberations and denies the reality of anything beyond this debate. The resonance with Pound's own 'constellation' of 'modern poetry ${ }^{34}$ is made explicit with the ironic reference to '[Alexander] Pope'. In Pound's careful construction of a 'modern movement' and his role as 'the purveyor of geniuses ${ }^{35}$ he turns from the feminist sensibility which informs Loy's poetic to ponder instead the abstract question of her affinity with the logopoeia of Augustan satire-'not of me or you Sister Saraminta | Of no more or less | Than the fit of Pope's mitres [metres]'.

In 'Sister Saraminta' Loy offers a complex representation of her self and her writing. 'Saraminta' is an example of Loy's characteristic anagrammatical self-representations which occur in her other satires ('Giovanni Franchi,' ‘The Effectual Marriage’ 1917, 'Lion’s Jaws’ 1920), here a rendering of 'mina as art' or 'mina's art.' So the two figures, 'me or you Sister,' allow a multiple point of view that enables Loy simultaneously to speak her self as subjectivity ('me', 'I'), of herself as object (as her work), and of her self as subject-in-process (as coming into being through her work). The 'Sister' here, evoking the figure of a nun in contrast to the 'Baby Priests' of the poem, asserts the gender of all of these positions and emphasises their shared ground of experience. 
Loy's poem progresses to explore further the gendered embodiment of the speaker:

Here am I in lilac print

Preposterously no less than the world flesh and devil

Having no more idea what those are

What I am

Than Baby Priests of what "He" is

or they are-

The image of 'lilac print' which stands distinct from the 'flowered flummery' mentioned in Songs to Joannes (1917) and the 'falling ferns' on the dress of the 'threewomen' in 'Giovanni Franchi', carries a particular valence although it does, as in these other poems, represent a soft, feminine sensibility and selfhood that juxtaposes with masculine self-assertion. As in Songs to Joannes Loy draws on the imagery of Greek mythology to examine contemporary heterosexual power relations. The origins of the name of the lilac (Syringa vulgaris), one of the most popular garden shrubs in Edwardian England, lies in the Greek myth of the nymph Syrinx; pursued by Pan she was transformed into reeds to escape his advances. In Ovid's Metamorphoses Pan then takes the reeds, which vibrate when he sighs, and fashions a pipe from them: the lilac is one of the genus of flowering woody plants (syringa) that have hollow stems or stems that can be hollowed out to make flute or pipe stems. ${ }^{36}$

In 'The Black Virginity' the lilac print is deliberately differentiated from the stark contrasts that dominate the poem, from the chiaroscuro of the opening image, to 'Parallel lines' that juxtapose the 'white muslin girl's school' with the 'black silk cloaks' of the seminarians. As a coloured 'print' or patterned fabric these draperies suggest a combination of different elements which can be assumed. Therefore, 'Here am I in lilac print' suggests the assumption of an identity, 'I,' as a process of accumulation of the right clothes. This 'I' nonetheless, is associated 
with 'the world flesh and devil,' the temptations of the immanent that are renounced in the baptismal ceremony. The association of the disavowed immanent with the feminine is 'preposterous', but is also implicitly violent and appropriative. The pursuit of the eroticised feminine, implied by the mention of 'lilac' and repeated in a seminarian's attempt to pick 'a high hung fruit, ${ }^{37}$ recasts the iterated stories of attempted rape in ancient mythology which result in the transformation of (speaking) female subjects into mute nature. The story of Syrinx has close parallels with both that of Daphne and Philomel, and like the myth of Philomel it involves the denial of the victim's voice; where Philomel is silenced through mutilation before her transformation into a nightingale, Syrinx becomes the vessel for Pan's musical expression of desire. As Loy's 'The Black Virginity' remarks on the perpetuation of women's oppression; 'It is an old religion that put us in our places.' The 'lilac' is the denied, disavowed and desired (female) body, but by calling into question gender essentialism ('print'), Loy challenges the reduction of women to a silenced corporeality.

The only actual dance that features in 'The Black Virginity' is the oxymoronic depiction of the seminarians 'tripping measured latin ring-a-roses': the real intricacies of existence are avoided in a fruitless intellectual circularity, imagined as a childish dance. In contrast, the state of unknowing admitted by the speaker in the last stanza of poem is articulated in terms which emphasise an absence of closure or certainty; 'And all this | As pleasant as bewildering | Would not eventually meet | I am for ever bewildered [. . .] what nonsense'. The disjunctive syntax, disruptive line ends and repetition of 'bewilder' underscores the eccentric movement that is described, a bodily going-astray that traces an alternate path to the girdling lines of Catholic theology. In 'The Black Virginity' Loy resists the stagnating effect of rigid absolutes and antitheses and ironically depicts the attempt to co-opt her poetry into a Poundian modernism as a version of the pursuit of parthenoi. Loy's reworkings of ancient myths of pursuit, rape and transformation recur in her writing on dance, as discussed below; in utilising them Loy highlights 
the tensions between the expressive possibilities of woman's corporeality and the cultural construction of woman as mute, natural body.

Given Loy's satirical depiction of male heterosexual lust in 'The Black Virginity' it is all the more surprising that her next substantial engagement with dance appears to endorse a gender binary of male active and female passive sexuality, and reinforce the 'places' and stories in which women traditionally have been put. Although identified by Sara Crangle as a drama in her edition of Loy's prose works, 'Crystal Pantomime' is actually a libretto for a ballet that was probably begun by Loy in the early 1920s when she indicates she is working on ballet ideas in a letter to Carl Van Vechten; 'I am sending you Fantasy Street because I know you can tell me what to do with it don't you think it would be wonderful as a ballet-in a review or even in Opera [...] I know the public would adore it if it was properly done \& I can design it in a way that would make em [sic] sorry they had to go on being alive after it was all over. ${ }^{38}$ The scenario for 'Crystal Pantomime' is an heterosexist narrative, ostensibly the story of a 'beautiful slim maiden' who 'see[s] her life in [a] crystal' globe shown to her by a witch (p.151), it involves primarily 'her waiting' while the actions of the ballet concern 'the adventures of the young man that she [the maiden] will eventually marry' (p.152). Formally the libretto displays none of the experimental use of lighting, kinetic scenery or language that characterise Loy's earlier futurist dramas Collision and Cittäbapini, both published in Rogue magazine in 1915. These plays subjugate the individual to the forces of the modern world and marginalise the human in a dynamic theatrical space, as Julie Schmid describes, they 'portray a futurist universe in which the movement of atoms and the rhythms of the city overwhelm the solitary man on the stage and become the focus of the performance. ${ }^{39}$ In contrast 'Crystal Pantomime' works with stable characters, plot and a conventional climax and is deliberately archaic; set in a non-specific past, 'the times when maidens waited at home while the youths went out into the world' (p.152), it draws on stock scenes ('a country fair' p.153) and 
characters ('a beautiful mermaid' p.158, a 'fairy queen' p.159), to culminate in the 'honeymoon' of the maiden and the youth (p.160) and the vision of a 'baby' on its way (p.161). In her autobiographical prose writings, which remained unpublished in her lifetime, and in her long poem Anglo-Mongrels and the Rose (1925), Loy returns repeatedly to her past and it is clear that the legacy of her Victorian, middle-class, British childhood resonates in the motifs, narratives and femininities of 'Crystal Pantomime'. ${ }^{40}$ The importance of dance to her work is apparent at other points of her autobiographical writing: Loy sees her infant self, in the manuscript for The Child and the Parent as a dancer, 'looking like an untrained ballet-dancer . . . hopping about among the furniture of the day-nursery, ${ }^{41}$ and in the novel Insel 'Crystal Pantomime' is the only one of her written works that the protagonist 'Mrs Jones' describes in detail.

Loy's comments to Van Vechten suggest that she was concerned with producing a popular and (financially) successful piece and statements in the 'Crystal Pantomime' libretto reiterate this approach; 'The subject of the ballet will appeal to everyone because, being so simple, the high-brows will enjoy it with that humorous compassion they afford for the souvenir sentiments and the general public will "get" it without effort' (p.153). Indeed Loy's greatest concerns with her ballet are with staging, costume and theme, thus she pays close attention to conceptualising and describing the mise-en-scène of 'Crystal Pantomime,' its 'crystalline appearance' (p.152), the 'magic lantern scenery' which 'enhances the ethereal effect of unreal beauty' and the bright colours of costumes and lights (p.153). The libretto explains scenes, costumes and dances in great detail including a scene called 'Ladies in a Love Storm' which involves an invasion by 'amorin', a dance by 'the spirit of the marble' who 'must be [.. . ] a very fine acrobat contortionist' (p.155) and the appearance of 'the cortege of Venus in a shell drawn by horses like the white china figures I collect' [sic] (p.159). Loy draws on artefacts and cultural references-not just the china mentioned here but a 'merry-go-round [. . . in Paris with silver horses and mermaids' (p.155), the pages of 'old story books' (p.161), 'old prints' (p.160) and 'an amusing cubistic 
pattern'(p.160)—to generate the bricolage of her ballet design. Her use of non-traditional costuming, floor-work and the majority of her dancers on flat feet indicates her awareness of the changes in ballet at the time, though not necessarily the vocabulary to express this. An early scene involving the maiden, her mother and her grandmother requires both older women to have 'ballet-dancer's legs' to indicate their affiliation to a Victorian past, with the more agile mother wearing 'a draped bustle with a tail of bunched drapery such as hung down the back of bustle skirts—but the skirt is absent— the movements of her dance give the poker-swan-likeeffect of the period' (p.154). The mother's costuming and footwear-the implication of the 'poker-swan-like-effect' is that she is en pointe in the classical ballerina's painful performance of an ideal of weightlessness — connect her closely to the Victorian ladies who populate Loy's autobiographical writings. Dressed in the draperies of their Victorian repression (corsets and bustles), these ladies are required to enact an ideology of women's purity and sexual denial that they also impose on their daughter's bodies: the caged bird, Loy's key image for these distorted femininities, is certainly related to the 'poker-swan' of the mother dancing in 'Crystal Pantomime'. ${ }^{42}$

Loy is interested in the bodies of her imagined dancers and the movements of their dances, describing for example 'the spirit of the marble' whose 'motion must identify itself with the circular rolling of the orb' (p.156). Elsewhere Loy mentions the 'leapfrogging' 'Nijinsky did in The Spirit of the Rose' which she feels will give 'an interesting modern rhythm' to an early scene in 'Crystal Pantomime' (p.153), and proposes her mermaids will 'dance the Russian dance' 'on the tip of one tail' (whilst suspended on wires) which will 'be most original' (p.158). At the core of the ballet Loy imagines a 'to-and-fro movement in the dance rhythm' (p.157), inspired by her observation of the 'together and apart dancing of insects in the air' which is repeated across the ballet and functions as its 'leit-motif (155). Loy is not a contemporary choreographer, but she is certainly aware of bodily affect and the expressive kinaesthetic produced in dance, seeing the 
figures in 'Crystal Pantomime' as capable of communicating complex meanings through their appearance and movement: 'the spirit of the marble' in his dance 'expresses the personification of objects through sentiment-and the stirring of the imagination at dusk, that apprehends some living entity in the phenomena of Nature that please or arouse the dream-sense' (p.156). The dancing body, as conceived by Loy here, can bring to life, embody and express the abstractions of the creative imagination. In the novel Insel Mrs Jones describes 'Crystal Pantomime' as a ballet she 'had for some while been conceiving,' and recounts the struggle to embody her creative ideas in the moving form; 'I only have to make some little people about five inches high' she declares 'and tell them what to dance'. ${ }^{43}$ Mrs Jones admits the impasse she reaches, explaining that 'It takes me hours [...] to remember it cannot be done. It is as if at the back of that memory stands another memory of having had the power to create whatever I pleased' (pp.85-86). This 'other memory', a sense of the expressive possibility of proprioception and its liberation of creativity, underpins Loy's impulse to make meaning in dance. It is the necessary inversion of Pound's 'dance of the intelligence', wherein dance becomes the primary term and not merely the vehicle in a metaphor of poetics.

Loy engages with modern ballet in 'Crystal Pantomime' and does not just deal in nostalgic bricolage. For all its endorsing of an heteronormative narrative which allows the 'youth' his 'wild oats episodes' (p.157) while the 'maiden' awaits rescue from a repressive Victorian maternal space, metaphorically represented at the end of the ballet as a 'dragon' the youth must defeat (which 'falls apart to reveal nothing but the maiden's mother holding up her lorgnette' p.160), 'Crystal Pantomime' does position itself as a contemporary piece with both direct (the reference to Nijinsky) and indirect echoes of the Ballet Russes. The more innovative or controversial of the Ballets Russes' productions such as Sacre de Printemps, Parade, or Les Noces were not necessarily their most successful, and their core repertoire included ballets with quite conventional plots; Le Marriage du Aurore (from Sleeping Beauty), Giselle and La Boutique Fantastique 
(The Magic Toyshop) for example. Loy's concerns with design reflects Diaghilev's aesthetic, seeking to create a total work of art that would capture the imagination of an audience. Moreover, by having the male dancer as the star of her ballet Loy was also intending the male body as a spectacular, erotic display, introducing the possibility of heterodox implications arising from his performance, as in some of the Ballets Russes productions. The sexual politics of 'Crystal Pantomime' are paradoxically modern: the youth has an affair with a married woman and he witnesses the dance of prostitutes; 'colored light ladies' who 'stroll up and down, pacing — their feet gripping the ground stealthily [. . .] exactly as I have observed it outside a shady hotel in Paris' [sic] (p.156).

Whilst retaining the patina of traditional, heteronormative romance 'Crystal Pantomime' introduces a sexualised corporeality exemplified by the bodies of the dancers and the playful erotic energy of the youth, and it constructs a viable viewing position from which a spectator could actively enjoy the sexual male body on display. This possibility is exemplified in a powerful image of the youth's awakening to promiscuity: as the 'colored light ladies' disappear into darkness at the end of their scene they are replaced by a cinematic effect which metonymically articulates the seduction of and by a watching audience; 'a large, lashy, luminous eye winks at him and is extinguished' (p.156). Such modern techniques (the dance steps, special effects, sexual narrative and male spectacle) reinforce a counter current in 'Crystal Pantomime', a retrojection that awakens the radical potential of this ballet, despite or even because of its attempts at popular appeal. The revisiting of narratives of the past, both personal and cultural, is a feature of Loy's autobiographical reworkings which, similar to 'Crystal Pantomime', write a modernist, feminist aesthetic out of the hybrid fragments of a Victorian, British childhood and an itinerant engagement with European avant-garde and popular culture. 
When Loy returns to the subject of dance later in her writing career, after her extended period of autobiographical prose writing in the 1930s and 1940s, she revisits some of the tropes of her earlier ideas about dance and women's bodies and considers the woman dancer who did the most to challenge Victorian constructions of acceptable womanhood and the repression of women's bodies. Loy's unpublished long poem on Isadora Duncan 'Biography of Songge Byrd' was completed in the early 1950s and in three poems in the 'Later Poems' section of Lunar Baedeker and Time-Tables (1958), published by Jonathan Williams, 'Stravinski's Flute,' 'Transformation Scene,' and 'The Song Of The Nightingale Is Like The Scent of Syringa' Loy engages with the Ballets Russes through the work of Igor Stravinsky. Debora Van Durme suggests the Lunar Baedeker and Time-Tables poems 'form a musical triptych' which reads 'like a poetic interpretation' of Stravinsky's Le Chant du Rossignol. ${ }^{44}$ This is a useful suggestion, but Durme reads these poems as primarily concerned with music and in doing so occludes the central aspect of Loy's triptych; that it examines the dancing body. Le Chant du Rossignol is a oneact ballet based on Hans Christian Anderson's story 'The Nightingale' and adapted by Stravinsky from his earlier opera Le Rossignol for Diaghilev's Ballets.

Le Chant du Rossignol premiered in Paris in February 1920 with set and costume-design by Henri Matisse and choreography by Léonide Massine. Loy was resident in Paris when the ballet was revived for the brief 1925 Ballets Russes season there, with innovative choreography by George Balanchine, reusing Matisse's designs but with a new costume for the Nightingale. This part was played in 1925 by Alicia Markova (born Lillian Alicia Marks in North London) who was just fourteen at the time; the costume designed for her by Matisse utilised the smooth body contours recognisable now as the standard ballet leotards of the contemporary ballerina, but shockingly innovative for its day: 
white silk tights all over, then white satin ballet shoes, large diamond bracelets around both ankles, the wrist of one arm, and the other just here above the elbow, a little white bonnet like a baby's and no hair to show. ${ }^{45}$

Loy's 'Stravinski's Flute' evokes Markova's appearance as a fragile white bird in Le Chant du Rossignol in its opening lines, in which 'The swan's neck stiffens | and the swan | starts from the swamps of Silence. ${ }^{46}$ The Nightingale's entrance in the ballet is as a captive bird, carried shoulder-high in a wooden cage, ${ }^{47}$ an image that has a powerful resonance in Loy's autobiographical writing. ${ }^{48}$ Though the reference to a 'swan' is anachronistic - it was not until later in her career that Markova danced and became closely associated with 'The Dying Swan' routine - ${ }^{49}$ she is invoked in Loy's poem as the natural moving form of Stravinsky's music: the Nightingale is choreographed to the flute part in Stravinsky's Rossignol. This, 'the most conspicuous flute part in his [Stravinsky's] oeuvre' is characterised by an 'insistent motivic reverberation' and 'repetition' ${ }^{50}$ and it was the dancer Markova who embodied these repetitions and reverberations in her performance as the nightingale.

Loy seeks to represent Markova's expressive physical movements firstly through the embodiment of the sound and structure of the music in the poem 'Stravinski's Flute,' and secondly through the structural play of phonemes and morphemes in 'The Song Of The Nightingale Is Like The Scent of Syringa.' In 'Stravinski's Flute' the dancer's body is aroused and brought to movement by music, with her inertia imagined as a miasmic location with alliterative echoes signalling the creation of the 'swan' from the 'swamps of Silence.' As exemplified by this line, 'Stravinki's Flute' works with an insistent synaesthesia that incorporates both the confusion of the senses and the oxymoronic description of sound as tangible space or object. Thus the music is described as a 'voice-evangel of loud ice,' and a 'strand of sound' becomes 'a rope into 
Nirvana'. The final lines of the poem reiterate the translations of affect and semantic displacements of sensual experience in phrasing which emphasises the harmony of somatic experience; 'To this listening | the mouth and the ear $\mid$ of music | are one.' The dancer's body that begins the poem thus persists in the insistent reference to the embodied experience of music.

In 'The Song Of The Nightingale Is Like The Scent Of Syringa' the body and embodied experience are central, but are displaced in a translation that is reflected in, and insistently repeated in, the verbal texture of the poem with its closely crafted phonemic translations. The link to Le Chant du Rossignol is signalled through the structural play with repetition, which directly alludes to Stravinsky's flute part, and through the references to 'Nanking' and 'Ming-dynasty' which evoke the Orientalist aesthetic of Matisse's designs for the ballet and his inspiration from Chinese porcelain. ${ }^{51}$ The poem consists in seventeen mostly one-word lines, each of which echo, rhyme or rework the core words of the poem, 'Song' and 'Syringa'. Underlying the poem is a logic of myth which, like the phonemic transformations, shifts one term, the 'song' of a nightingale, into the other, the scent of the 'syringa' or lilac. Between these two terms, and providing the link between them, is a woman's body. This body is evoked by the repeated references to sensual experience, and that this is a particular version of woman's body, captured by the mythic frames of Western culture, becomes apparent in what Durme identifies as a 'deliberate link' that Loy makes between Philomel and Syrinx (p.339). Philomel and Syrinx are transfigured women rendered speechless, and at the heart of their narratives stands their desired, pursued and then disavowed bodies.

I would fundamentally disagree with Durme's assertion that the myth of Philomel is not a 'vital part' of the meaning of the nightingale's song in Loy's poem - Durme mistakenly argues that this is 'merely an amusing frolic' in a piece that 'wants primarily to be a celebration of sensuality' (p.340). In fact the myths of Syrinx and Philomel are central to the poem and to the 
way in which Loy brings the woman dancer's body into the piece. Syrinx and Philomel are ultimately effaced in their mythic incarnations, carrying symbolic meaning only, they are transported into a natural state which denies their specificity. Loy's 'The Song Of The Nightingale Is Like The Scent Of Syringa' celebrates and gives meaning to the mute, moving woman's body, articulating a synaesthesia which is not a confusion but an excess of somatic meaning. The multiple presence of the dancer's body can be seen in the thirteenth line, 'ringer', a single word that means sound, reverberation, circular movement (all related to dance), but also a substitute (women metamorphosed into bird or plant) and a close similarity (nightingale and lilac, Philomel and Syrinx). Like scent and song the dancer's body communicates in a physical form and her presence persists despite denial: 'sing long | syringa | lingerer'.

The image of a dancer as 'Song-winged' bird that brings together these two Lunar Baedeker and Time-Tables poems is recapitulated in Loy's poetic biography of Isadora Duncan, 'Biography of Songge Byrd'. Although a small section was published in The Last Lunar Baedeker in 1982, the full poem remains unpublished; the typed manuscript held in the Loy Papers at the Beinecke Library is headed by a sheet that reads ‘This was about Isadora Duncan’ and is dated Spring 1952. ${ }^{52}$ Loy's publisher Jonathan Williams' interest in the poem is illustrated by his own Ripostes, a poem written for the Aspen Center of Contemporary Art Dance Performance in August, 1968 which featured Louis Falco, Carla Maxwell, Diane Mohrmann, Jennifer Muller and Sally Stackhouse. He quotes from two sections of Loy's poem (which is cited as 'Songge Byrd' by Williams), summarising the first section as 'Isadora Duncan is here adored as Songge Byrd,' and writing that 'Miss Loy delineates her | delicate bird's-foot-violet | approach in the asphodels. ${ }^{53}$ Williams' admiration for Loy's poem highlights specific aspects of her celebratory presentation of Duncan: Loy's attempt to express Duncan's dance in the lines of her poetry ('delineates'); her reworking of the bird-woman tropes that persist in her autobiographical writing (delicate bird's-foot'); her challenge to mythic stereotypes ('violet', 'asphodels'). His use of it in 
the published 1968 Aspen Center dance programme also connects Loy's portrayal of Duncan to contemporary modern dance innovators (both dancers and choreographers), and exemplifies the importance of 'Biography of Songge Byrd' and Loy's writing on dance; her prescient emphasis on kinaesthetics and the politics of the moving body became central concerns in twentiethcentury modern dance.

Loy's biography of Duncan celebrates her achievement as a woman artist, imagining her life as a 'Diva's pilgrim's progress' (p.6) from ‘a young and a fair girl' 'in Grecian clothes | waving branches of rose' (p.1) to a bereaved mother 'choking' on her grief (p.13). It is not clear whether Loy ever saw Isadora Duncan dance in a theatre for a paying audience, but she was connected to Duncan in various ways. Loy became acquainted with Gordon Craig, Isadora Duncan's lover at the time, in Florence in 1907 through her husband Stephen Haweis, and Loy's affair with a young Russian poet in Berlin in 1922 brought her into contact with the circle around Duncan and her husband, the Russian poet Sergei Esenin. ${ }^{54}$ Loy had enrolled her daughter Joella in the Duncan school in Potsdam in 1918 (founded by Elizabeth Duncan, Isadora's older sister), though she refused to let Joella relocate to London to help open a new branch of the school in 1923, moving her to Paris instead. ${ }^{55}$ The scathing remarks in 'Biography of Songge Byrd' about Duncan's siblings as 'cretins of culture' 'holding conferences | that barely pay expenses | on how to train a deaf-mute as | a Prima Donna' (p.6) suggest a less-thanpositive attitude to the Elizabeth Duncan School.

Isadora Duncan had come to fame in the early 1900s—her first professional theatre performance engagement was in 1895—and she was a well-established, and controversial, solo performer by the time of Loy's first acquaintance with her in Florence. Central to Duncan's theory of dancing was the idea of successive movement, and she saw the structure and universality of the wave as the key to understanding the 'beautiful rhythmic movements of the human body,' writing that 'all energy expresses itself through this wave movement. ${ }^{56}$ Duncan 
opposed her dance practice to traditional ballet and Diaghilev declared 'Isadora gave an irreparable jolt to the classical ballet of Imperial Russia [...] She pointed the way and Fokine and I followed. ${ }^{57}$ In a profound way, as Penny Farfan points out, 'Duncan claimed for women the right to participate actively in cultural production' or as Duncan put it in her manifesto 'The Dance of the Future' she sought to 'dance the freedom of women. ${ }^{58}$ Duncan's impact on the emergence of 'natural' dance as the core of the modern American tradition was huge, but during her life-time her celebrity and notorious refusal to conform, either bodily or morally, to norms of women's roles often overshadowed her dancing and dance theory. Mark Franko argues that 'Duncan wished to contest the Victorian experience of female culture' with her expressive body and the affectivity of her dance, resisting gendered binaries and instating 'through suggestive practice a new sort of social relation to the feminine body as an altered public space. ${ }^{59}$ Loy's 'Biography of Songge Byrd' is centrally concerned with the tensions between Songge Byrd's artistic and bodily expression, her 'untrammelled' utterance, 'few draperies' and 'legs of nature' (p.5), and the external responses to these which, in Loy's rendering, amount to exploitations of Duncan's celebrity and misunderstandings of her unorthodox feminine expression and bodily affect.

Duncan was deeply influenced by the Delsartian 'System of Expression,' which originated with the work of Francois Delsarte and, in its American manifestation, was closely associated with Harmonic Gymnastics (or movement for heath and symmetry). ${ }^{60}$ Delsartism drew on its originator's conception of the immanence of the spirit and his idea of a form of somatic semiotics in which one could 'read bodily gestures and positions as meaningful signs. ${ }^{61}$ According to Carrie Preston, 'in addition to shaping Duncan's performance form, Delsartism inspired her interest in the poses of classical antiquity and her Greek costumes' as it enshrined an idea of the free and natural with recourse to a classical past for its cultural validity. ${ }^{62}$ Loy was herself interested in therapeutic movement technique: she practised the Mensendieck System of 
Functional Movement in Florence after the birth of her daughter Joella and, as Tim Armstrong describes, demonstrated a 'sustained interest in bodily adaptation. ${ }^{63}$ Loy even 'invent[ed] her own bodily reform movement' (evidenced by her 1919 pamphlet Auto-Facial Construction) aimed at restoring a 'natural' harmony to the face through the exercise of 'Conscious Will', and in later life designed a 'Corselet' intended as '[a]n efficient supplement to physical culture exercises in the avoidance or correction of middle-age figure curvature ${ }^{64}$ Armstrong's conclusion is that Loy repeatedly 'stresses the element of performance and self-commodification in her technique [. . .] introducing décor into physical culture' (p.129). This combination of interest in the technique of the natural body, and in the décor of physical movement points to a common thread between Loy's different engagements with dance and foregrounds the intersection between bodily selffashioning and bodily self-expression that informs her understanding of the kinaesthetics of dance.

Throughout Loy's poem Songge Byrd is subject to and defined by the opinions of others; the poem opens with a 'blurred portrait' that 'clumsily' pictures her (p.1) and closes with an ex-lover's claim to vicarious fame; 'I was, you know, the illustrious | Songge Byrd's husband - -' (p.13). She is thus circumscribed by a third-person perspective which juxtaposes with the narrator's attempts authentically to represent Songge Byrd, as the narrator exclaims 'How can I | describe that woman's art -' (p.3). From 'High Born Isle' who recounts her youthful 'Bohemian' exploits with Songge Byrd (p.1), to advertising posters 'plastered' on the 'kiosks of Paris' (p.2), to the 'gossip's odds' (p.5), 'Hearsay' (p.6), and 'talk at dinners' that construct Songge Byrd as a 'celebrated sinner' (p.8), she is interpellated and constructed by bourgeois discourses of morality and (financial) worth. The prurient interest in Songge Byrd's 'procession of vice' fails to recognise the reality of 'The lovely antics | of her flittering spirit | in an expressional paradise' (p.5), a misconstruing of Songge Byrd's life and art which highlights how oppositional meanings produced on and through the performed/performing body can be commodified and co-opted 
into frames of reference which dissipate any revolutionary force. The speaker of the poem even admits her own culpability; 'Having not wholly | bypassed publicity,' she is 'stunned' on meeting 'Songge Byrd' to find her 'unsoilable' and 'intrinsic innocence' (p.11).

'Biography of Songge Byrd' contrasts the external opinions which commodify Songge Byrd (Songge Byrd as circulated in discourse) to the actual experience of watching her performance (Songge Byrd's embodied art), and at this point of the poem Loy draws on the same technique of synaesthesia that structures 'Stravinski's Flute' and repeats the motif of dancing woman's body-as-song that informs 'The Song Of The Nightingale Is Like The Scent Of Syringa.' That Songge Byrd is imagined as a nightingale is suggested both by the final image of her 'choking on the falling | feather of a nightingale,' and by her depiction in the third section which uses the language and imagery of 'Poem 28' of Bliss Carmen's Sappho One Hundred Lyrics 'With your head thrown backward ... From that throat, the throbbing | Nightingale's' to describe how Songg Byrd 'threw her throbbing fragile throat | up' (p.3). The mythic resonances of Loy's description of Songge Byrd are expanded and multiplied by Williams in his Ripostes: both Loy and her poem's Songge Byrd are associated by Williams with 'violets' and 'asphodels' suggesting a link to Persephone, another manifestation of the desired-pursued woman from Greek myth, but one associated with death and loss, rather than transformation (both Loy and Duncan were dead by the time of Williams’ poem). By presenting Duncan, the solo woman dancer, as a 'Songge Byrd' Loy is not simply displacing one form of artistic expression (dance) into another (singing) but emphasising a corporeal continuum that underlies this woman's art and giving voice to it (gesture-as-song) whilst reaffirming it as a bodily expression. The uncertain boundary between song and dance is expressed in language which emphasises the physical embodiment of music; 'bounded | with the notes,' 'Leapt to the impetus of the musics' (p.4), and offers a synaesthetic description of her song as taste and touch; 'globules of melody,' 'gentle fingers of her voice' (p.3). This serves to highlight Loy's central point about Duncan's dance; 
that its performance exceeds description in words. Thus Songge Byrd's body-song surpasses the bounds of language and the real: 'Her flitting | motion to her song | must make her seem unreal | she was so ariel | so unbound' (p.3).

Loy focuses, in the central sections of her poem, on Songge Byrd's relationships with two men, 'John Silence' and 'Gerald Screams,' the respective fathers of her two children 'Whisper' and 'Echo'. Silence, satirically described as 'conceiver of Opera Houses | for Marionettes voices' (p.4) represents Gordon Craig, whose idea of the Über-Marionette was intended to purge theatre of the 'weaknesses and tremors of the living flesh'. ${ }^{65}$ Silence epitomises the artist who denies the body and authentic expression, he is a 'pre-war poseur' who espouses 'nonsense' (but still finds patronage of 'several thousand sterling' for a theatre) (p.7). Loy uses the phrase 'subjugated throat' to indicate how Songge Byrd relinquishes her autonomy in her erotic and amorous relationship with Silence, whilst he is pre-eminently concerned with 'posterity' and 'pencil-sharpening' (p.7). Screams, the 'the multi-emperor of Consolidated Steam' (p.9) represents Paris Singer, son of the millionaire sewing-machine magnate, and the father of Duncan's son Patrick. He is the essence of materialism and industrial capitalism who offers 'Songge Byrd' 'gold' until his 'wealth' is threatened by the strain this 'bounteous amorosa' puts on 'his health' (p.9). Songge Byrd's authentic art stands in direct contrast to these two men, to both the 'puppets' of Silence's theatre (p.7) and Screams' millions of dollars.

A notable absence in the poem is any reference to Duncan's husband, Esenin, and this lacuna extends to incorporate Duncan's whole involvement with Russia in the 1910s and with the communist politics that led to her exile from America before her death in 1927. Loy's 'Biography of Songge Byrd' is staged as an exploration of the politics of (women's) self and bodily expression in art, so deliberately occults any other political philosophy that might have informed Duncan's work and life. Instead, Loy emphasises Songge Byrd's status as a woman who exceeds established norms of femininity, expressed through a series of oxymorons and 
incongruous phrases; 'incelibate | vestal,' 'unmarrigeable perfection' 'anachronous wife,' ‘so refused | survivor' (p.12). Loy is also concerned to explore Songge Byrd's position as mother, a fundamentally female role, and to articulate a sense of the grief of a mother who loses her children. Translating the death of Duncan's two children by drowning in a car accident, into a fall from a tree, a tragic attempt by them to celebrate 'delight in aerial heritage' (p.10), Loy describes Songge Byrd's loss as 'the agony of suddenly | aimless motherhood' (p.10). Her children are envisaged as inextricable from her art, their absence leaves her 'Songless' and 'muted' (p.10). On revisiting the site of their death Songge Byrd imagines them still alive but can 'exhale no aria | for hear-sing offspring || Only an arid croak' (p.12). The portmanteau 'hearsing' communicates the position of Songge Byrd's children as echoes of and expressions of her art, whilst also describing their passing (they have been 'hearsed' or carried to the grave). It is a term that, finally, also speaks of the essence of her art, the kinaesthetic empathy in the reception of dance that moves the spectator to an active apperception of the moving body they are witnessing; making their 'hearing' also a form of 'singing.'

In his end-note to Ripostes Williams records that 'He also wishes to note that poems by Stevie Smith and Joel Oppenheimer were on the dancing-ground of his mind when these ripostes were executed. ${ }^{96}$ Oppenheimer's 'The Dancer' evokes the expressive power and particularity of the dancing woman 'Katy,' while Smith's 'The Ballet of the Twelve Dancing Princesses' juxtaposes the innocence and 'split second' beauty of schoolgirls dancing with something 'equivocal' just beyond the scene which signals both world historical events (the poem is sub-titled 'Hayes Court, June 1939') and the ephemeral purity of the dance. Williams points out the affinities between Loy and Duncan, as creative women, in his Ripostes, connecting their artistic utterances through images of dance. He describes the climax of 'Biography of Songge Byrd' as 
swan-song laughing with

swine-song,

dancing over the heath

with death $-{ }^{67}$

The concatenation of references in these lines, which reach out to mythology (the ancient belief that the mute swan sings before its death), modern ballet images (the Dying Swan routine) and the classic twentieth-century ballet film The Red Shoes, with its origin in Hans Christian Anderson's story which has the doomed girl dancing 'over the heath' to find the executioner who will cut off her feet with the bewitched red shoes, conflate multiple stories of (the dancing) woman's inevitable destruction. Crucially though the two women, Duncan in her 'swan-song' and Loy in her 'swine-song's uncompromising poetic challenge (Loy infamously opened her Songs to Joannes with an image of 'Pig Cupid') are presented by Williams 'laughing' as they are 'dancing'. In concurrence with Williams' celebration in Ripostes, this article has endeavoured to show that the writer Loy, like the dancer Duncan she celebrates, refuses to accept the judgments of a patriarchy that would have them decorous, decent and dumb.

The dynamics and narrative of 'Biography of Songge Bird' derive primarily from Loy's interest in Duncan as a woman artist who spoke with and through her body, and also one who was co-opted (through and because of her bodily meanings) into a celebrity identity that occluded her actual practice. In the rapacious gossip over Songge Byrd's exploits in her poem Loy recasts the mythical motifs of lust and pursuit she employs elsewhere in her writing on dance and that signal the attempt to capture woman-as-nightingale, or woman-as-lilac. By challenging and recasting these motifs in her dance writing Loy questions gendered stereotypes that restrict women as creative individuals. From her earliest engagements with ballet and dance which energetically relate to her feminist modernist aesthetic, to the struggle with non-verbal 
expression in her 'Crystal Pantomime', to the later poems which examine more prominently kinaesthetics and the gender politics of the dancer's body, Loy reads and writes dance as a woman writer concerned to articulate the specificity of women's experience. It is the particularity of embodied expression that interests Loy in dance, an expression which resists the abstractions of intellection and revalues perception that is based in, and returns to, the body as a site of meaning. But the traces of dance are tenuous and the authenticity or purity of its meanings vulnerable to exploitation. Dance, like Duncan's, performs significance but the body is also a performance, one which can be directed and invested with sense by the embodied subject, but which also can be taken over and ascribed particular connotations by others. It is this co-option of the dance, and its possible meanings, that Loy resists in Pound's modernism and disparages in her poetic biography of Duncan. In all her writing on ballet and dance Loy's intention is to interrogate and experiment with the way corporeal meaning is made and how corporeality can be part of the meanings of language. As a woman writer this places her firmly in a tradition which seeks accurately to articulate women's lived bodily experience.

For permission to quote from Mina Loy's unpublished writings - The Child and the Parent and 'Biography of Songge Byrd' - grateful acknowledgement is given to Roger Conover, Literary Executor of Loy's Estate.

${ }^{1}$ See Tanya Dalziell, 'The Sound of an Idea: Music in the Modernist Writings of Mina Loy and Gertrude Stein,' in Music and Literary Modernism: Critical Essays and Comparative Studies, ed. Robert McPharland (Newcastle: Cambridge Scholars Publishing, 2009), 110-125; Debora Van Durme, '"Conjuring Melodies From Arid Air": Mina Loy and Pound's Melopeoia,' Cambridge Quarterly, 37, No. 2 (2008), 324-348. On Loy and Jazz see Tanya Dalziell, 'Mourning and Jazz in the Poetry of Mina Loy,' in Modernism and Mourning, ed. Patricia Rae (Lewisburg: Bucknell University Press, 
2006), 102-117; Andrew Michael Roberts, 'Rhythm, Self and Jazz in Mina Loy's Poetry,' in The Salt Companion To Mina Loy ed. Rachel Potter and Suzanne Hobson (Cambridge: Salt Publishing, 2010), 99-128.

${ }^{2}$ Susan Jones, Literature, Modernism \& Dance (Oxford: Oxford University Press, 2013), 8, 28. The most significant previous study, Felicia M. McCarren's Dancing Machines: Choreographies of the age of mechanical reproduction (Stanford: Stanford University Press, 2003), focuses almost entirely on men modernists and avant-gardists; puzzlingly, Jones makes no mention of McCarren's earlier book in her study.

${ }^{3}$ See Wendy K. Perriman Willa Cather and the Dance: 'A Most Satisfying Elegance' (Madison NJ: Fairleigh Dickinson University Press, 2009) for an account of Cather's engagement with dance; Djuna Barnes wrote multiple newspaper articles on social dance, dance trends and popular dancers in New York in the 1910s; Marianne Moore wrote two articles (on Anna Pavlova and on George Balanchine and Igor Stravinsky's 'Circus Polka') for Dance Index Magazine in the 1940s. ${ }^{4}$ Mina Loy, 'Sketch of a Man on a Platform', Rogue 1.1 (1 April, 1915), 12.

${ }^{5}$ F. T. Marinetti 'Manifesto of Futurism' in Futurism: an anthology, eds Lawrence Rainey, Christine Poggi and Laura Wittman (New Haven and London: Yale University Press, 2009), 51. On Loy’s complex relationship to Italian Futurism see Natalya Lusty, 'Sexing the Manifesto: Mina Loy, Feminism and Futurism,' Women: a cultural review 19, No. 3 (2008), 245-260.

${ }^{6}$ See Cinzia Sartini Blum, 'Marvellous Masculinity: Futurist Strategies of Self-Transfiguration through the Maelstrom of Modernity' in Modernism and Masculinity, ed. Natalya Lusty and Julian Murphet (Cambridge: Cambridge University Press, 2014), 100.

${ }^{7}$ Cincinnati Inquirer, 19 March, 1911, quoted in Mary Simonson, Body Knowledge: Performance, Intermediality and American Entertainment at the Turn of the Twentieth Century (Oxford: Oxford University Press, 2013), 149. 
${ }^{8}$ New York Dramatic Mirror 4 November, 1914, 19; The Billboard 1 February, 1908, 10; The Sydney Morning Herald, 15 July, 1911, 5.

${ }^{9}$ Marinetti is likely referring to the Italian ballo-grande, the huge, spectacular productions that gained international popularity in the 1880s and contrast to the Romantic ballet developed in France between 1830 and 1850.

${ }^{10}$ F. T. Marinetti, 'Manifesto of Futurist Dance' in Futurism: an anthology, ed. Lawrence Rainey, Christine Poggi \& Laura Wittman (New Haven and London: Yale University Press, 2009), 235, 237.

${ }^{11}$ Marinetti, 'Manifesto of Futurist Dance', 235.

${ }^{12}$ F. T. Marinetti, 'The Variety Theatre' in Futurism: an anthology, 127.

${ }^{13}$ The Theatre Magazine March 1908; The Daily Mail, 15 January, 1903.

${ }^{14}$ In the nineteenth century in France and Britain women were increasingly presented dressed in male attire (en travestie) in the male roles in ballet.

15 'Pazzarella' and 'Sacred Prostitute' were first published in Stories and Essays of Mina Loy, ed. Sara Crangle (Champaign IL and London: Dalkey Archive Press, 2011), 65-97; 188-215.

${ }^{16}$ Ramsay Burt, The Male Dancer: Bodies, Spectacle, Sexualities (London \& New York: Routledge, 1995), $12 \mathrm{ff}$.

${ }^{17}$ Peter Stoneley A Queer History of the Ballet (London \& New York: Routledge, 2007), 77.

18 'Heterodox' is the term coined by Lynn Garafola to describe the non-normative masculine roles developed in the Ballets Russes' repertoire, see 'The Travesty Dancer in NineteenthCentury Ballet,' Dance Research Journal 17, No. 2 and 18 No. 1 (1985-86), 39. The term is also used by Ramsay Burt in The Male Dancer.

${ }^{19}$ Burt, The Male Dancer, 84.

${ }^{20}$ Stoneley, A Queer History of the Ballet, 7. 
${ }^{21}$ Mina Loy, The Lost Lunar Baedeker, ed. Roger L. Conover (Manchester: Carcanet, 1997), 85.

${ }^{22}$ Ibid., 184.

${ }^{23}$ Jones, Literature, Modernism \& Dance, 205, 207.

${ }^{24}$ Ezra Pound 'The Serious Artist' in Literary Essays of Ezra Pound, ed. T. S. Eliot (London: Faber and Faber, 1954), 41-57, 52.

${ }^{25}$ Ezra Pound, 'A List of Books,' The Little Review 4, No. 11 (March 1918), 58.

${ }^{26}$ Ezra Pound, 'Irony, Laforgue, and some Satire', Poetry XI, No. 2 (November 1917), reprinted in Literary Essays of Eæra Pound, 281; Carolyn Burke, 'Getting Spliced: Modernism and Sexual Difference,' American Quarterly 39 (1987), 99.

${ }^{27}$ Ezra Pound, $A B C$ of Reading (New York: New Directions, 1934), 38.

${ }^{28}$ Pound, 'A List of Books,' 58.

${ }^{29}$ Dee Reynolds and Matthew Reason, 'Introduction' in Kinesthetic Empathy in Creative and Cultural Practices (Bristol \& Chicago: Intellect, 2012), 20; see also Matthew Reason and Dee Reynolds, 'Kinesthesia, Empathy, and Related Pleasures: An Inquiry in Audience Experiences of Watching Dance,' Dance Research Journal 42, No. 2, 49-75.

${ }^{30}$ McCarren, Dancing Machines, 81-82.

${ }^{31}$ Mina Loy, 'Modern Poetry,' Charm: The Magarine of New Jersey Home Interest, 3, No. 3 (April 1925); reprinted in The Lost Lunar Baedeker, 158.

32 'The Black Virginity' was first published in Others 5, No. 1 (December 1918), 6-7, and then reprinted in the Others for 1919 anthology (New York: Nicholas L. Brown, 1920), 110-12.

33 'Hermetically sealed' is the phrase that the 'Houseless Loony' uses to describe the avant-garde dilettantes in Loy's play 'The Pamperers' where he also suggests the instability of their isolation; 'No human beings can be so polished, so sequestered, so hermetically sealed . . . but that they may still be able to aspire. I am the apostle of Fraternity. I find my brother in the most secluded 
coward' (first published in The Dial 69, No.1, 1920; reprinted in Stories and Essays of Mina Loy, ed. Sara Crangle, 171).

${ }^{34}$ Mina Loy, 'Modern Poetry', The Lost Lunar Baedeker, 158.

${ }^{35}$ Ibid.

${ }^{36}$ As discussed below in relation to 'Biography of Songge Byrd,' Bliss Carmen’s incredibly popular volume, Sappho: One Hundred Lyrics (first published 1904) is one likely source for the myths of Syrinx and Daphne in Loy's poetry: Syrinx features in poems 27, 30 and 35, and Daphne in poems 30 and 94.

${ }^{37}$ This too has a source in Carmen's Sappho: One Hundred Lyrics (see his 'Poem 53').

${ }^{38}$ Loy letter to Carl Van Vechten n.d. (c.1925), Carl Van Vechten Papers, Beinecke Rare Book and Manuscript Library, Yale. 'Crystal Pantomime' was first published in Stories and Essays of Mina Loy, 151-161, the typed manuscript held in the Mina Loy Papers at the Beinecke Rare Book and Manuscript Library is undated. Subsequent references to 'Crystal Pantomime' will be cited parenthetically in the text.

${ }^{39}$ Julie Schmid, 'Mina Loy’s Futurist Theatre', Performing Arts Journal 18, No.1 (January 1996), 4.

${ }^{40}$ For more on Loy's writing on Victorian femininities see Sandeep Parmar's Reading Mina Loy's Autobiographies: Myth of the Modern Woman (London: Bloomsbury: 2013). I examine the way Loy represents, and negotiates her relationship with, the repressed/ repressive maternal body, Victorian femininities and her British Victorian childhood in her unpublished autobiographical writing and in the poetic sequence Anglo-Mongrels and the Rose in my previous publications including Mina Loy's Modernist Aesthetic' unpublished PhD thesis, University of Leeds, 1997; 'Autobiography/Auto-mythology: Mina Loy's Anglo-Mongrels and the Rose', in Representing Lives: women and autobiography ed. Alison Donnell and Pauline Polkey (New York: St. Martin's Press, 2000), 270-79; 'Empire, Motherhood and the Poetics of the Self in Mina Loy's Anglo-Mongrels 
and the Rose', Lifewriting 6, No. 1 (2009), 61-76; reprinted in Poetry and Autobiography ed. Jo Gill and Melanie Waters (New York \& London: Routledge, 2011), 59-74. For a further discussion of Loy's examination of the body of the (Victorian) grandmother and her relationship to contemporary women’s bodies and feminine fashions see my “'Consider Your Grandmothers': modernism, gender and the New York Press", Media History 7, No.1 (2001), 47-56.

${ }^{41}$ Mina Loy, The Child and the Parent, Mina Loy Papers, Beinecke Rare Book and Manuscript Library, Yale, Series II, Box 1, Folder 12, Chapter IV 'Arrival of the Scene of an Accident', 18. Parmar dates The Child and the Parent c.1932-1936 (Reading Mina Loy's Autobiographies, 175.) ${ }^{42}$ The unpublished autobiographical writings in the Loy Papers at the Beinecke Library contain multiple examples of the image of the caged bird as a metaphor for women's suppression in the Victorian era, see for example the short extract 'Ladies in an Aviary' published in The Last Lunar Baedeker, 316. Parmar discusses Loy's bird imagery and its relation to both Victorian women and a 'child's incipient consciousness' (see Reading Mina Loy's Autobiographies, 37).

${ }^{43}$ Mina Loy, Insel, ed. Elizabeth Arnold (Brooklyn \& London: Melville House Publishing, 2014), $84,85$.

${ }^{44}$ Durme, 'Conjuring Melodies', 341, 342. Durme argues that 'it is not inconceivable that the poem that appears between 'Stravinski's Flute' and 'The Song of the Nightingale' in Lunar Baedeker \& Time-Tables, ‘Transformation Scene,' 'describes a fragment from Le Chant Du Rossignol ('Conjuring Melodies' $341 n 45$ ), but the evidence for this is scant. It is just as likely to evoke scenes from Sacre Du Printemps, Les Noces or another of the Ballets Russes' primitivist ballets, or indeed an unrelated ballet performance.

${ }^{45}$ Memoir notes from Dame Alicia Markova Collection, Howard Gotleib Archival Research Center, Boston University; quoted in Tina Sutton, The Making of Markova: Diaghilev's Baby Ballerina 
to Groundbreaking Icon (New York and London: Pegasus Books, 2013), 116. See Sutton for the response to Markova's costume (116-118).

${ }^{46}$ Mina Loy, Lunar Baedeker \& Time-Tables (Highlands, N.C.: Jonathan Williams, 1958), 77; reprinted in Mina Loy The Last Lunar Baedeker, ed. Roger L. Conover (Manchester: Carcarnet, 1985), 219.

${ }^{47}$ My references to a performance of Le Chant du Rossignol draw on the 1999 reconstruction of Balanchine’s 1925 ballet by Millicent Hodson and Kenneth Archer with Les Ballets de MonteCarlo, a film of which is available at https://vimeo.com/14292064 . See also Hodson and Archer's article about staging the ballet 'To Catch a Nightingale: Reconstructing Le Chant du Rossignol, http://www.hodsonarcher.com

${ }^{48}$ See fn 42 above.

${ }^{49}$ The 'Dying Swan' had been choreographed to Saint-Saens's cello solo for Anna Pavlova in 1905 and this routine became a key part of Markova's repertoire after 1942: she danced 'The Dying Swan' on Sid Ceaser's variety TV show Your Show of Shows in 1952, (see Sutton, The Making of Markova, 564), was photographed in the role by Carl Van Vechten in 1948, and was painted in the role by Vladimir Tretchikoff in his Alicia Markova 'The Dying Swan' (1949)

${ }^{50}$ Durme, 'Conjuring Melodies', 341, 342.

${ }^{51}$ Mina Loy, Lunar Baedeker \& Time-Tables, 80; reprinted in The Last Lunar Baedeker, 218. On Matisse's designs for Le Chant du Rossignol see Juliet Bellow, 'Disorienting Decoration: Henri Matisse and Le Chant du Rossignol,' in Modernism on Stage: The Ballets Russes and the Parisian AvantGarde (Burlington VT and Farnham UK: Ashgate, 2013),167-208. As a designer actively producing and selling her interior design pieces through her shop in Paris during the mid-1920s, Loy would have been very aware of the style trends and influences deriving from the Ballets Russes. 
${ }^{52}$ Mina Loy 'Biography of Songge Byrd', Mina Loy Papers, Beinecke Rare Book and Manuscript Library, Yale, Series II, Box 5, Folder 130. Subsequent references will be cited parenthetically in the text using the pages numbers on the unpublished typescript.

${ }^{53}$ Jonathan Williams, Ripostes (Stuttgart: Edition Domberger, 1968), n.p.

${ }^{54}$ See Carolyn Burke, Becoming Modern: The Life of Mina Loy (Farrar, Straus and Giroux: New York, 1996), 315-6.

${ }^{55}$ See Burke, Becoming Modern, 327.

${ }^{56}$ Isadora Speaks: Isadora Duncan, ed. Franklin Rosemont (San Francisco: City Lights Books, 1981), 37,45 .

${ }^{57}$ Quoted in Walter Terry, Isadora Duncan: Her Life, Her Art, Her Legacy (New York: Dodd Mean and Company, 1963), 40, 42.

${ }^{58}$ Penny Farfan, Women, Modernism, and Performance (Cambridge: Cambridge University Press, 2004), 103; Isadora Duncan “The Dance of the Future”, The Art of the Dance, ed. Sheldon Cheney (New York: Theatre Arts, 1928), 63.

${ }^{59}$ Mark Franko, Dancing Modernism/ Performing Politics (Bloomington: Indiana University Press, 1995), 2, 16.

${ }^{60}$ For an account of the development of Delsartism in the USA see Nancy Lee Chalfa Ruyter, 'American Delsartism: Precursor of an American Dance Art,' International Journal of the History of Sport 26, No. 13 (2009), 2015-2030.

${ }^{61}$ Carrie J. Preston, Modernism's Mythic Pose: Gender, Genre, Solo Performance (Oxford: Oxford University Press, 2011), 61.

${ }^{62}$ Ibid., 153.

${ }^{63}$ Burke, Becoming Modern, 118, fn; Tim Armstrong, Modernism, Technology and the Body: a cultural study (Cambridge: Cambridge University Press, 1998), 122. 
${ }^{64}$ Armstrong, Modernism, Technology and the Body, 129; 'Inventions/Corselet (Armour for the body) n.d.' in the Mina Loy Papers, Beinecke Rare Book and Manuscript Library, Yale, Series II, Box 7, Folder 186. Loy's 'Corselet' is discussed in Jessica Burstein, Cold Modernism: Literature, Fashion, Art (University Park PA: Pennsylvania State University Press, 2012), 179-184.

${ }^{65}$ Edward Gordon Craig, 'The Actor and the Uber-Marionette' (1907), in On the Art of the Theatre (London: Mercury, 1962), 81.

${ }^{66}$ Jonathan Williams, Ripostes, n.p.

${ }^{67}$ Ibid. 